\title{
Identifying essential summer habitat of the endangered beluga whale Delphinapterus leucas in Cook Inlet, Alaska
}

\author{
Kimberly T. Goetz ${ }^{1, *}$, Robert A. Montgomery ${ }^{2}$, Jay M. Ver Hoef ${ }^{1}$, \\ Roderick C. Hobbs ${ }^{1}$, Devin S. Johnson ${ }^{1}$ \\ ${ }^{1}$ National Marine Mammal Laboratory, Alaska Fisheries Science Center, National Marine Fisheries Service, \\ National Oceanographic and Atmospheric Administration, Seattle, Washington 98115-6349, USA \\ ${ }^{2}$ Department of Fisheries and Wildlife, Michigan State University, East Lansing, Michigan 48824, USA
}

\begin{abstract}
In response to the critically low numbers of beluga whales Delphinapterus leucas in Cook Inlet, Alaska, USA, the US federal government listed this isolated population as endangered in 2008. Despite the curtailment of subsistence hunting in 1999, the abundance of Cook Inlet belugas has remained low ( $<400$ whales), with no obvious signs of recovery. As habitat is a critical component of population viability, our goal was to identify habitat selected by beluga whales. We developed predictive habitat models from the distribution and group size of beluga whales observed between 1994 and 2008. We fit a 2-part hurdle model to describe the physical and anthropogenic factors that influence (1) beluga presence (mixed model logistic regression) and (2) beluga count data (mixed model Poisson regression). Beluga presence was negatively associated with sources of anthropogenic disturbance and positively associated with fish availability and access to tidal flats and sandy substrate. Beluga group size was positively associated with tidal flats and proxies for seasonally available fish. We produced habitat maps for beluga presence, group size, and the expected number of belugas in each $1 \mathrm{~km}^{2}$ cell of Cook Inlet. These maps distinguish suitable habitat which could prove integral to the sustainability and recovery of the Cook Inlet beluga whale population.
\end{abstract}

KEY WORDS: Beluga whales · Delphinapterus leucas · Cook Inlet · Poisson · Logistic regression · Habitat selection · GIS · Generalized linear mixed model · GLMM

\section{INTRODUCTION}

The endangered status of Cook Inlet (Alaska, USA) beluga whales Delphinapterus leucas is one of the most pressing conservation issues facing Alaskan marine mammals in the past decade. This population is the most geographically isolated (Laidre et al. 2000) and the most genetically distinct ( $\mathrm{O}^{\prime}$ Corry-Crowe et al. 1997) of the 5 known beluga populations inhabiting Alaskan marine waters. Although there have been periodic sightings of belugas around the Gulf of Alaska (Laidre et al. 2000), recent evidence suggests that the Cook Inlet population resides exclusively in the inlet year round (Hobbs et al. 2005). Calkins (1989) estimated the 1979 Cook Inlet beluga population to be 1293 animals. Since this time, the beluga population in Cook Inlet has steadily declined. Between 1994 and 1998, beluga abundance decreased by nearly $50 \%$ (Hobbs et al. 2000). This decline was due in part to subsistence hunting. Alaskan natives voluntarily ceased the beluga hunt in 1999 and later that same year the National Marine Fisheries Service (NMFS) enacted an official hunting moratorium (Pub. L No. 106-31, section 3022, 113 Stat. 57, 100). Despite these efforts, abundance estimates of belugas in Cook Inlet have remained low (375 animals in 2007 
and 2008 compared to 653 in 1994), with no notable signs of recovery (Hobbs et al. 2008). In response to the low numbers of beluga whales in Cook Inlet, the US federal government listed this isolated population as endangered under the US Endangered Species Act in October 2008.

Understanding the habitat conditions selected by Cook Inlet belugas is paramount to the sustainability and recovery of the population. Previous studies have documented the significance of coastal areas and mudflats to the presence of Cook Inlet belugas (Huntington 2000, Moore et al. 2000, Goetz et al. 2007), and qualitatively identified habitat variables such as prey aggregations, predator distribution, salinity, temperature, bathymetry, ice cover, oil and gas activity, and vessel traffic that may influence the distribution and abundance of these whales (Moore et al. 2000). To date, Goetz et al. (2007) provided the only quantitative models to predict summer beluga presence in Cook Inlet.

Because Cook Inlet belugas feed, calve, and molt during the summer, models developed to depict summer habitat must incorporate covariates that link these behaviors to potential habitat, either directly or indirectly. Processes that may disrupt such behavior, such as anthropogenic disturbances, are also important to consider and may add valuable information when predicting habitat. The objective of this analysis was to predict Cook Inlet beluga summer habitat using data from a broader time period than previously considered (Goetz et al. 2007 analyzed 1993 to 2004 data as compared to 1994 to 2008 data analyzed here) and to model previously unused environmental data (e.g. intertidal substrate, distance to anthropogenic factors, and rivers with anadromous fish). We present a 2-part hurdle model to identify the proximate mechanisms that influence not only beluga whale presence but also beluga whale group size. Specifically, this study examines the ecological relationship between beluga summer distribution/ group size and (1) bathymetry; (2) distances to tidal flats, rock, and sand substrates; (3) distances to human communities and oil platforms; and (4) distances to streams with anadromous fish and rivers with low, medium, and high flow accumulation (referring to the total stream flow upstream of a given location).

Identifying suitable habitat within a species range is essential for devising effective conservation plans, especially when a species is rare, such as the Cook Inlet beluga, and when an entire population range is unlikely to be protected due to competing interests. Determining habitat selection for marine mammals is particularly challenging because they utilize a 3dimensional spatial environment over time. Despite this challenge, several studies have modeled marine mammal habitat using environmental variables such as depth, bathymetric slope, distance to shore, sea surface temperature, and salinity (Gregr \& Trites 2001, Baumgartner et al. 2003, Schick et al. 2009). The models developed in our analysis predict summer habitat based on both beluga presence and the number of beluga whales in a group relative to covariates that are thought to be important to the life history of beluga whales. Therefore, the ultimate goal of this study was to identify habitat selected by Cook Inlet beluga whales, which might prove critical to this already endangered population.

\section{MATERIALS AND METHODS}

\section{Study area}

Cook Inlet is a $370 \mathrm{~km}$ tidal estuary in south-central Alaska which stretches from Kachemak and Kamishak Bays in the south to the northern reaches of Knik and Turnagain Arms near Anchorage (Fig. 1). The Inlet drains into the Gulf of Alaska and covers an area of approximately $20000 \mathrm{~km}^{2}$ with $1350 \mathrm{~km}$ of coastline (Rugh et al. 2005). The coastline has a variety of different substrates, with reefs and rock more common in the south, and mudflats and sand almost exclusively in the north (Sharma \& Burrell 1970). Although Cook Inlet is very shallow with a mean depth of 60 to $70 \mathrm{~m}$ (Bouma et al. 1977, Muench et al. 1978), it exhibits one of the most extreme tidal cycles in the world, with tidal variation ranging from 6 to $9.5 \mathrm{~m}$ and currents often greater than $6.2 \mathrm{~m} \mathrm{~s}^{-1}$ (Moore et al. 2000).

\section{Aerial survey protocol}

To document the distribution and group size of beluga whales, we flew aerial surveys in Cook Inlet each June/July from 1993 to 2008. Using methods described by Rugh et al. (2004), the surveys were flown in a twin engine aircraft with high wings and flying capability greater than $6 \mathrm{~h}$. Each survey period ranged between 3 and $9 \mathrm{~d}$ and included both coastal and offshore transects. The aircraft was flown at an altitude of $244 \mathrm{~m}$ while maintaining a ground speed of approximately $185 \mathrm{~km} \mathrm{~h}^{-1}$. The majority (>70\%) of the search effort was focused on near-shore waters where belugas are typically seen during the spring 


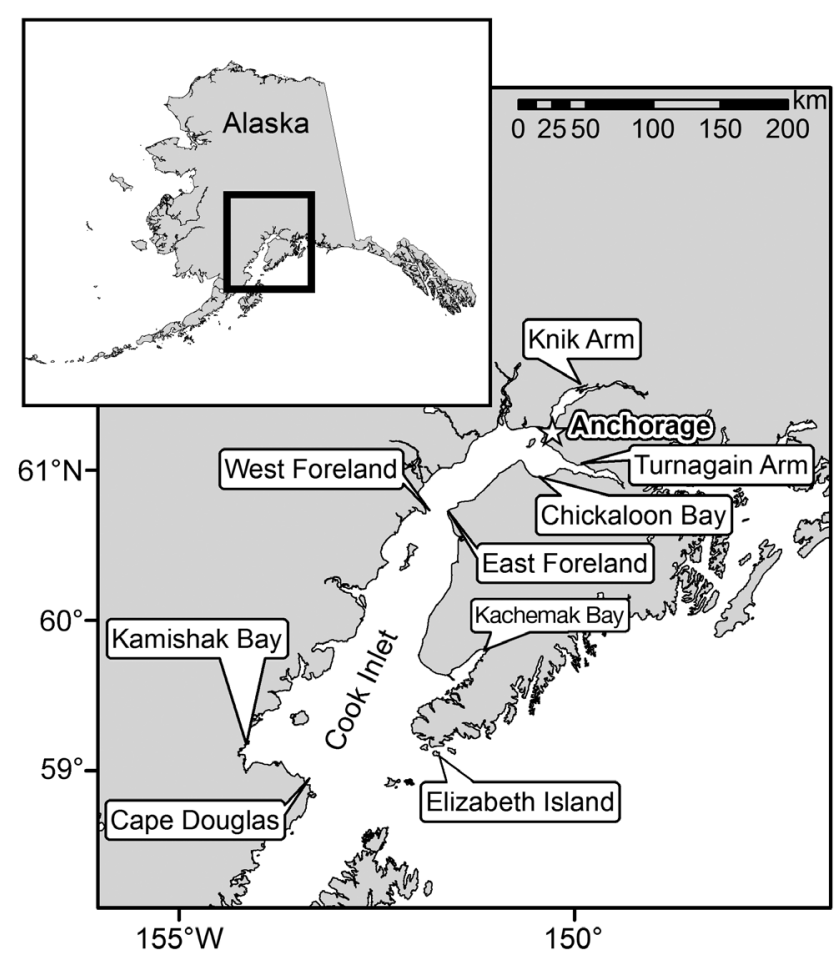

Fig. 1. Cook Inlet study area located in south-central Alaska, USA

and early summer. An inclinometer angle of $10^{\circ}$ was used to keep the aircraft approximately $1.4 \mathrm{~km}$ from the shoreline (Rugh et al. 2004). This search distance and survey altitude maximized the visual range relative to the size of the search image while minimizing disturbance to the whales.

Two observers were positioned on the port side (towards the shore) of the plane, and 1 observer and 1 data recorder were on the starboard side. While flying coastal transects, observers were audibly and visually isolated from one another and reported their observations through the intercom system. The survey was considered on-effort when all observers were actively searching. Weather conditions and equipment issues occasionally resulted in off-effort data $(<5 \%)$ which were excluded from the analysis. When whales were observed, the plane turned and passed directly over the beluga group to determine its location using a handheld GPS unit. The plane then made several passes around the aggregation and the 2 port-side observers tallied the number of animals and assigned an overall grade to the pass (A to $\mathrm{F}$ for excellent through poor). The pass quality was based on the overall visibility of the group (accounting for sea state, sighting distance, glare, and the condition of the observation window), irre- spective of the number of whales at the surface. Once the 2 observers recorded 4 high-quality passes (A or B), the crew rotated, and the remaining observer and data recorder counted on the port side of the aircraft until they also obtained 4 high-quality passes. In most cases, there were 16 high-quality counts for each group of belugas encountered. The number of counting passes was occasionally reduced when group sizes were small ( $<5$ animals) or when air traffic precluded additional circling time. As a mechanism to reduce the number of outliers (extreme low or high counts), the median value of each observer's median count was assigned to every beluga group. In other words, the group size of each beluga group is the median value of all the observers' counts, and each observer's count is the median value from 1 to 4 high-quality passes.

\section{GIS analysis}

Annual survey data from 1994 to 2008, including $68788 \mathrm{~km}$ of on-effort track data and 321 point locations of beluga whale groups, were imported in ArcGIS 9.2 (Environmental Systems Research Institute; Fig. 2). Data from the 1993 survey were excluded due to differences in survey methodology; observers were not aurally isolated to allow paired independent observations, and track line effort was inconsistent with other years. All track lines were buffered by $2.8 \mathrm{~km}$ to represent the maximal viewing distance of the observers (approximately $1.4 \mathrm{~km}$ on each side of the aircraft). We divided Cook Inlet into a grid lattice of $1 \mathrm{~km}^{2}$ cells (hereafter referred to as habitat units). Only those habitat units surveyed at least once were included in this analysis.

We obtained over 1 million depth soundings throughout Cook Inlet from the National Oceanographic and Atmospheric Administration's (NOAA) Electronic Navigation Charts (www.nauticalcharts. noaa.gov/csdl/ctp/encdirect_new.htm, accessed September 2008) and the National Ocean Service Hydrographic Data Base (http://nhd.usgs.gov/data.html, accessed September 2008). Soundings were recorded as point locations with associated values at mean lower low water, when water is often absent from nearshore areas. Therefore, we added $9.0 \mathrm{~m}$ (representing the intertidal range) to simulate maximum tidal height. We interpolated these points to raster to create a seamless bathymetric layer (BATHDEPTH), and then assigned a bathymetric value to each habitat unit based on the intersection of the habitat unit centroid with BATHDEPTH. 


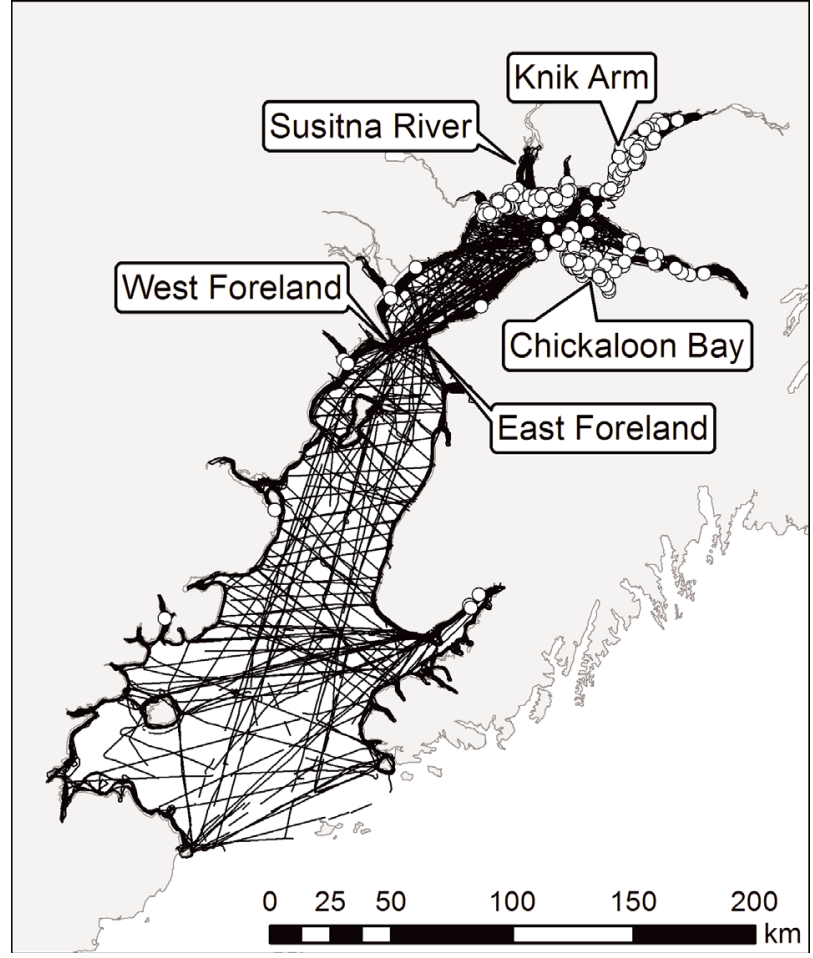

Fig. 2. Delphinapterus leucas. On-effort survey track lines (black) with beluga group sightings (white circles; $\mathrm{n}=321$ ) from 1994 to 2008

Shore zone surveys were flown by Coastal and Oceans Resources Inc. to evaluate coastal substrate type (Harney et al. 2008; http://alaskafisheries.noaa. gov/shorezone/, accessed September 2008). From the substrate data, we identified 2 types that are important to beluga whale distribution and group size, i.e. rock and sand. Because the coastal substrate is indicative of bottom substrate near the coast and beluga whales are most commonly associated with coastal areas, we believe these data may provide information in determining potential beluga habitat. We then calculated the nearest distance from each habitat unit to these 2 covariates (DISTSAND, DISTROCK; see Figs. S1 \& S2 in the supplement at www. int-res.com/articles/suppl/n016p135_supp.pdf).

Since belugas are restricted to marine waters, all distance calculations accounted for natural obstacles by calculating the shortest path around features (islands, sandbars, and bays) from the center of each habitat unit to the nearest covariate. In addition to coastal substrate types, tidal flats were extracted from an Environmental Sensitivity Index (ESI, i.e. data which are used to characterize estuarine environments and wildlife according to their sensitivity to oil) for the Cook Inlet region (http://response. restoration.noaa.gov/, accessed September 2008). From this dataset, we calculated the nearest distance from each habitat unit to tidal flats (DISTTFLAT; Fig. S3 in the supplement).

Several forms of anthropogenic disturbance occur in Cook Inlet, but we focused our analysis on 2 types: human communities and oil platforms. We collected data on 16 human communities around Cook Inlet. As many of these communities had coastal development spread several kilometers along the shore of Cook Inlet, we mapped their extent using existing digital boundary layers and aerial imagery. We then calculated distances from each habitat unit to the nearest human community (DISTCOMM; Fig. S4 in the supplement). Similarly, we collected data on the distribution of oil platforms in Cook Inlet (www.inletkeeper. org, accessed September 2008). Again, we calculated nearest distance from each habitat unit to each oil platform (DISTOIL; Fig. S5 in the supplement).

Distance to anadromous fish streams was calculated as an index of prey availability using data from the 2008 Alaska Department of Fish and Game's (ADFG) Sport Fish Division Anadromous Waters Catalog (AWC), which summarizes the known species of salmonids inhabiting streams draining into Cook Inlet (see www.adfg.alaska.gov/sf/SARR/AWC/index. $\mathrm{cfm}$ ? ADFG=data.GIS). Although all 5 species of salmon are found in Cook Inlet (Calkins 1989, Vos 2003, Johnson \& Weiss 2007), we selected data on the 4 species that would be running upstream during the June/July survey periods, which coincided with their peak availability in Cook Inlet (Moore et al. 2000). We derived the spatial location of streams with Chinook salmon Oncorhynchus tshawytscha, sockeye salmon $O$. nerka, chum salmon $O$. keta, and pink salmon $O$. gorbuscha. Similar to the covariates discussed previously, we calculated nearest distances from each habitat unit to rivers containing the different anadromous fish species (DISTCHNK, DISTSOCK, DISTCHUM, DISTPINK; Figs. S6-S9 in the supplement).

Since the AWC is based on anecdotal reports from the public and is believed to represent only $50 \%$ of the streams containing anadromous fish (see www. adfg.alaska.gov/sf/SARR/AWC/index.cfm?ADFG= main.overview), we also used flow accumulation as a mechanism to distinguish among tributaries entering Cook Inlet. Flow accumulation provides a cumulative measure of flow into the inlet from each river and is indicative of river basin size but does not account for seasonal and annual variability due to snow melt and precipitation. In this way, flow accumulation may be a proxy for beluga prey abundance. We obtained a 
2-arcsecond digital elevation model of Alaska from the US Geological Survey (USGS; http://seamless. usgs.gov/). Using hydrographic ArcGIS shapefiles obtained from the AWC and USGS seamless data distribution system, we derived a point shapefile depicting the location of rivers and streams entering Cook Inlet. We assigned flow accumulation values to each point following methods presented by Goetz et al. (2007). The output resulted in rivers that were categorized as low, medium, or high flow accumulation based on summary statistics. Rivers with flow accumulation values ranging from the minimum to the first quartile were considered low, those with values from the first quartile to the third quartile were classified as medium, and rivers with values above the third quartile were considered high. The final 3 covariates were created by calculating the distance from each habitat unit to low, medium, and high flow accumulation rivers (DISTLOW, DISTMED, DISTHIGH; Figs. S10-S12 in the supplement).

\section{Habitat modeling}

We used a 2-part or hurdle model to analyze beluga habitat suitability. This model assumes that different mechanisms determine the presence and count (i.e. group size) among the population of interest (Zuur et al. 2009). In the first part of the hurdle model, a binomial distribution is used to model the probability that a 0 (absence) or 1 (presence) is observed given various environmental covariates. In the second part, the non- 0 count data (group size) are modeled using a Poisson distribution in relation to the same set of environmental covariates.

For both parts of the hurdle model, we used the glmmPQL package in $\mathrm{R}$ ( $\mathrm{R}$ version 2.10.0, www.cran. r-project.org), to run a generalized linear mixed model (GLMM) with a penalized-quasi likelihood (PQL). Because we were interested in predictive versus explanatory power for predicting beluga presence and group size, we found the GLMM approach superior. As a final check, we re-ran a subset of the data using both the GLMM and a generalized additive mixed model (GAMM) and found no qualitative differences. GLMMs provide powerful tools for fitting and analyzing non-Gaussian grouped data, because they include both fixed and random effects often observed within ecological data (Bolker et al. 2009). The PQL algorithm uses mixed effects linear fitting as opposed to least-squares fitting to update the fixed effects and estimate the mean (Schall 1991). In most GLMMs, random effects account for most of
Table 1. Covariates utilized in the 2 parts of the hurdle model examining beluga whale occurrence and group size in Cook Inlet, Alaska, USA

\begin{tabular}{|c|c|}
\hline Covariate & Abbreviation \\
\hline $\begin{array}{l}\text { Number of times each habitat unit was } \\
\text { sampled per year }\end{array}$ & SAMP \\
\hline Bathymetric depth (m) & BATHDEPTH \\
\hline Distance from coastal sand substrate $(\mathrm{km})$ & DISTSAND \\
\hline Distance from coastal rock substrate (km) & DISTROCK \\
\hline Distance from tidal flats (km) & DISTTFLAT \\
\hline Distance from human communities $(\mathrm{km})$ & DISTCOMM \\
\hline Distance from oil development (km) & DISTOIL \\
\hline $\begin{array}{l}\text { Distance from rivers with annual Chinook } \\
\text { salmon runs }(\mathrm{km})\end{array}$ & DISTCHNK \\
\hline $\begin{array}{l}\text { Distance from rivers with annual sockeye } \\
\text { salmon runs }(\mathrm{km})\end{array}$ & DISTSOCK \\
\hline $\begin{array}{l}\text { Distance from rivers with annual chum } \\
\text { salmon runs }(\mathrm{km})\end{array}$ & DISTCHUM \\
\hline $\begin{array}{l}\text { Distance from rivers with annual pink } \\
\text { salmon runs }(\mathrm{km})\end{array}$ & DISTPINK \\
\hline $\begin{array}{l}\text { Distance from low flow accumulation } \\
\text { rivers }(\mathrm{km})\end{array}$ & DISTLOW \\
\hline $\begin{array}{l}\text { Distance from medium flow accumulation } \\
\text { rivers }(\mathrm{km})\end{array}$ & DISTMED \\
\hline $\begin{array}{l}\text { Distance from high flow accumulation } \\
\text { rivers }(\mathrm{km})\end{array}$ & DISTHIGH \\
\hline
\end{tabular}

the over-dispersion, but this can be unrealistic, especially in cases of rare or elusive species when there is often an overabundance of 0s (absences; Venables \& Ripley 2002). Whereas some functions attempt to fix this overdispersion, PQL methods simultaneously estimate the variance component of the random effects along with the regression coefficients.

We included the same 13 covariates in both parts of the model (Table 1) and ran correlation matrices to test the level of covariate dependency. Since highly correlated variables ( $r>0.70$ ) contribute equally to the model, the covariate that was thought to be least biologically meaningful was removed (details for each part of the hurdle model are provided in the following 2 subsections). To determine the significance of the habitat variables, we used a backward elimination approach, starting with the full model and removing non-significant variables one at a time. Because some habitat units were surveyed up to 14 times per year, we also included the number of times a cell was surveyed as a covariate (SAMP) to account for sampling bias. We incorporated Cell ID as a random effects term in both parts of the hurdle model to account for repeated sampling of habitat units among years. In addition, we used the exponential autocorrelation model to allow for temporal autocorrelation across years for a given cell. 
Hurdle model Part I: GLMM for beluga presence

We first modeled the binary response variable (presence or absence) using a mixed model (logistic regression). After running a correlation matrix, we found that BATHDEPTH, DISTLOW, DISTSOCK, and DISTPINK were highly correlated $(r>0.70)$ with other covariates and thus removed these 4 variables from the analysis (see Table S1 in the supplement at www.int-res.com/articles/suppl/n016p135_supp.pdf). Our initial model included DISTROCK, DISTSAND, DISTTFLAT, DISTCOMM, DISTOIL, DISTCHNK, DISTCHUM, DISTMED, DISTHIGH, and SAMP, with Cell ID as the random effects term.

To estimate areas of beluga habitat versus nonhabitat, we used a receiver operator characteristic (ROC) curve to evaluate the predictive accuracy of the model (Goetz et al. 2007). ROC analysis measures how well a receiver is able to detect a signal in the presence of noise. In this case, a beluga is either present or absent in a particular habitat unit, and the ROC curve predicts a threshold of a given variable at which a beluga is present. This optimal threshold optimizes errors of omission versus errors of commission. The area between the ROC curve and the $45^{\circ}$ line (Redfern et al. 2006) measures the discriminatory ability of the model to correctly classify a species as present or absent (Thuiller et al. 2003). Area under the receiver operator curve (AUC) values range from 0.5 (no discriminatory ability) to 1.0 (perfect discriminatory capability; Pearce \& Ferrier 2000). The ROC library (Atkinson \& Mahoney 2004) was used for ROC and AUC analysis of the model. Based on the calculated threshold value from the ROC curve analysis, we classified habitat suitability as either beluga habitat or non-habitat areas.

Hurdle model Part II: GLMM for beluga group size

For the second part of the model, we used beluga whale group size as the response variable and modeled the subset of the data where belugas were present using a mixed model (Poisson regression). In the small number of cases where several beluga groups were observed in the same habitat unit over the survey period $(\mathrm{n}=14)$, the median counts were summed. In this model, only DISTPINK and DISTROCK were highly correlated $(r>0.70)$ with other covariates and were therefore removed from the analysis (Table S2). Our starting covariates included BATHDEPTH, DISTSAND, DISTTFLAT, DISTCOMM, DISTOIL,
DISTCHNK，DISTCHUM，DISTSOCK，DISTLOW, DISTMED, DISTHIGH, and SAMP, with Cell ID as the random effects term.

Combining the 2 model parts

We mapped the results of the 2 GLMMs individually, as well as their product (i.e. multiplication), into geographic space. All covariates were spatially represented by grids with $1 \mathrm{~km}^{2}$ resolution and were multiplied by their corresponding parameter estimate to produce a visual representation of habitat suitability. The product of the 2 habitat suitability grids (derived from the probability of beluga presence and the expected group size, given that a group was present) resulted in an overall habitat suitability map showing the expected number of belugas in each grid cell.

\section{RESULTS}

\section{Hurdle model Part I: GLMM for beluga presence}

The results from the first part of the model showed that all variables were significant $(p<0.05)$ and were therefore retained. The temporal autocorrelation difference of $1 \mathrm{yr}$ was $5.81 \times 10^{-7}$, and thus the difference among years was insignificant. The final model did not include the temporal autocorrelation structure. The absence of structure in the autocorrelation did not strongly affect the significance levels of the covariates and thus all covariates were included in the final model. The results of this model indicate that the probability of belugas being present during the summer is greater closer to rivers with Chinook salmon runs $(p<0.01)$, rivers with medium flow accumulation inlets $(p<0.01)$, tidal flats, and areas with sandy coastal substrate. In contrast, the probability of observing belugas decreased closer to rivers with chum salmon, rivers with high flow accumulation inlets, human communities, oil development, and coastal areas with rocky substrate (Table 2).

We generated a probability of beluga presence map using the final parameter estimates from the first part of the hurdle model (Fig. 3). As we were only interested in the habitat effect and not the location variation by cell surveyed, we did not include the random effects term when mapping the model. We standardized on a SAMP value of 1 , meaning that the map shows the probability of observing a beluga given that the cell was surveyed at least once in a 
Table 2. Delphinapterus leucas. Covariate estimates for the final generalized linear mixed model for beluga presence in Cook Inlet, Alaska, from 1994 to 2008. Abbreviations as in Table 1

\begin{tabular}{|lrcc|}
\hline Covariate & Coefficient & SE & $\mathrm{p}$ \\
\hline SAMP & 0.245 & $6.551 \times 10^{-3}$ & $<0.0001$ \\
DISTSAND & -0.008 & $3.366 \times 10^{-3}$ & 0.017 \\
DISTROCK & 0.025 & $8.698 \times 10^{-4}$ & $<0.0001$ \\
DISTTFLAT & -0.177 & $5.047 \times 10^{-3}$ & $<0.0001$ \\
DISTCOMM & 0.006 & $6.407 \times 10^{-4}$ & $<0.0001$ \\
DISTOIL & 0.003 & $4.302 \times 10^{-4}$ & $<0.0001$ \\
DISTCHNK & -0.009 & $1.883 \times 10^{-3}$ & $<0.0001$ \\
DISTCHUM & 0.009 & $2.057 \times 10^{-3}$ & $<0.0001$ \\
DISTMED & -0.019 & $2.166 \times 10^{-3}$ & $<0.0001$ \\
DISTHIGH & 0.024 & $1.095 \times 10^{-3}$ & $<0.0001$ \\
\hline
\end{tabular}

given year. The overall probability of belugas being present in what we considered habitat ranged from 0 to 0.01 . This indicates that there is only a $1 \%$ chance that belugas will be present in a particular cell at any one survey time in the areas where they are expected to occur.

The ROC curve resulted in a 0.002 probability threshold for the final model in which values greater than 0.002 were classified as 'habitat' and values below 0.002 were considered 'non-habitat.' Within the study area, this threshold resulted in $2857 \mathrm{~km}^{2}$ of habitat ( $<15 \%$ of the study area) important for beluga presence (Fig. 4). An AUC value of 0.86 indicated that the model was able to correctly distinguish between beluga presence and absence $86 \%$ of the time after accounting for all covariates. While the model predicted habitat in several small coastal areas south of the Forelands, the majority $(>60 \%$ ) of predicted habitat occurred north of East and West Foreland, specifically in Knik Arm, Chickaloon Bay, and the Susitna River Delta (Fig. 4).

\section{Hurdle model Part II: GLMM for beluga group size}

The results of the second part of the hurdle model showed that the temporal autocorrelation difference of $1 \mathrm{yr}$ was $1.80 \times 10^{-8}$. As with the first part of the model, we assumed that there was no difference among years and ran the model without the temporal autocorrelation structure. In the full model, only DISTTFLAT and DISTMED were significant $(p<0.05)$ factors for predicting beluga group size. After performing backwards elimination, the final model included 3 significant $(p<0.05)$ coefficients: DISTSAND, DISTTFLAT, and DISTHIGH (Table 3). The results of this model indicated that larger group sizes

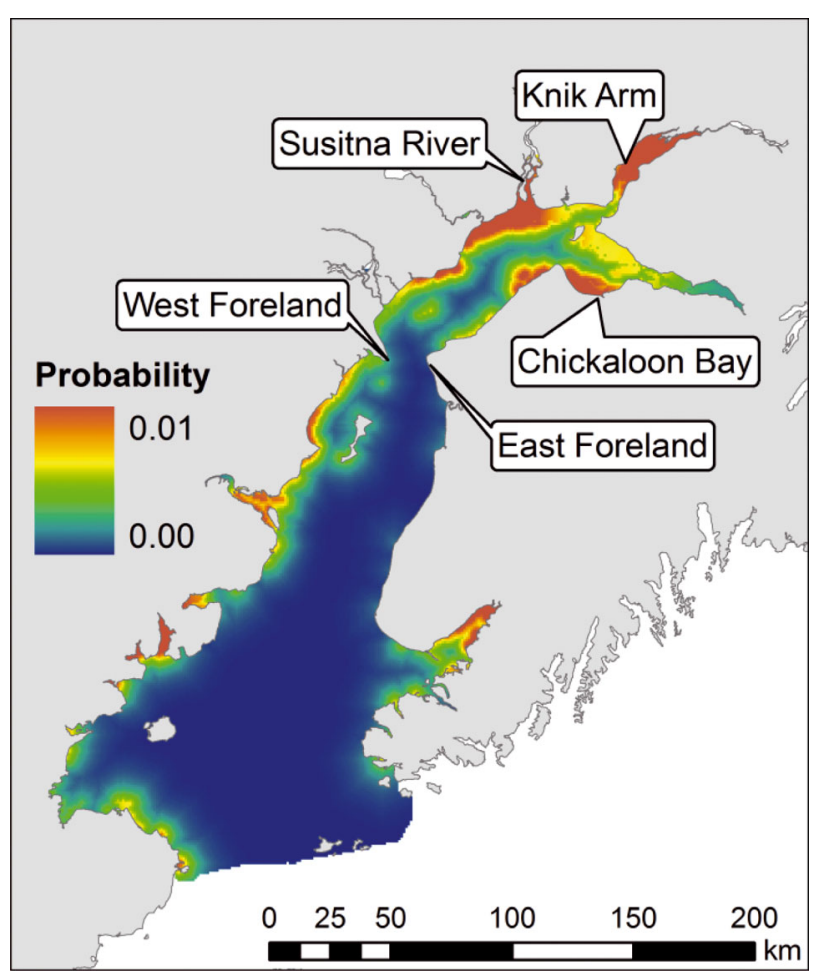

Fig. 3. Delphinapterus leucas. Probability of beluga presence during the summer estimated by the generalized linear mixed effects model using logistic regression

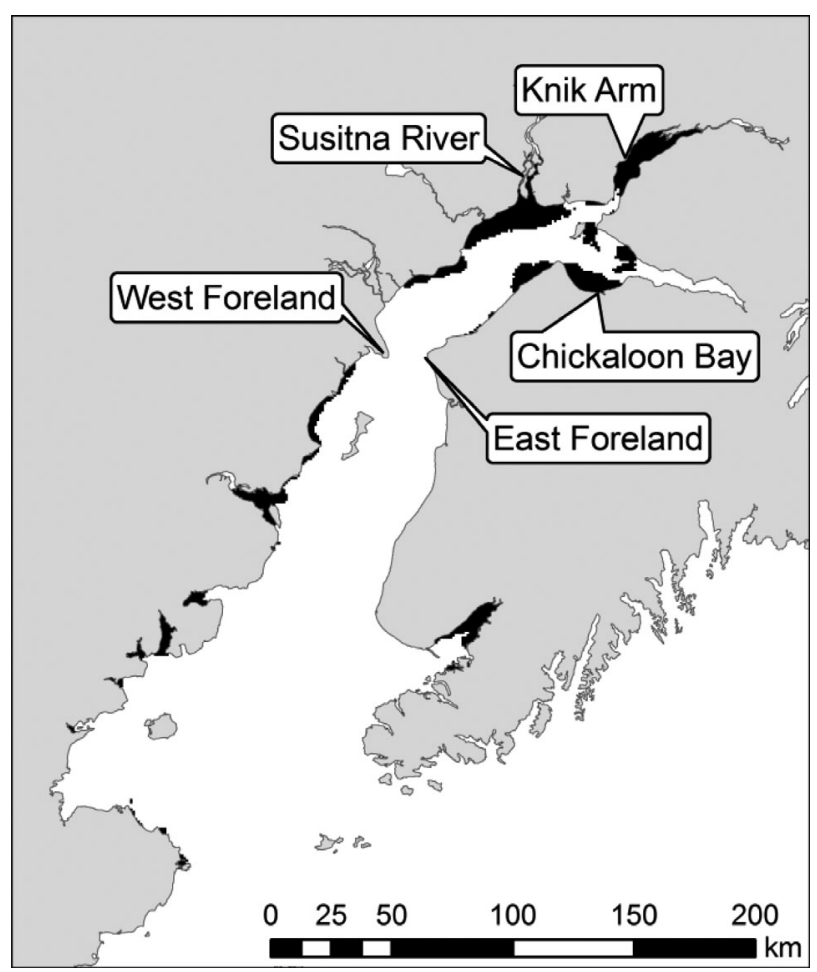

Fig. 4. Delphinapterus leucas. Summer habitat (black) predicted by the generalized linear mixed effects model for beluga presence 
Table 3. Delphinapterus leucas. Covariate estimates for the final generalized linear mixed model for beluga group size in Cook Inlet, Alaska, from 1994 to 2008

\begin{tabular}{lrcc} 
Covariate & Coefficient & SE & $p$ \\
\hline DISTSAND & 0.071 & $1.134 \times 10^{-2}$ & $<0.0001$ \\
DISTTFLAT & -0.243 & $5.580 \times 10^{-2}$ & $<0.0001$ \\
DISTHIGH & -0.010 & $4.580 \times 10^{-3}$ & 0.025 \\
\hline
\end{tabular}

tend to be closer to rivers with high flow accumulation and closer to tidal flats but that group size decreases closer to coastal areas with sand substrate (Table 3).

We mapped the model results spatially to provide a visual representation of the second part of the model. Because we were not interested in the location variation by cell surveyed, we did not include the random effects term when mapping the second part of the model; instead, only the fixed effects were visually represented (Fig. 5). The Poisson distribution function specified the expected group size when belugas were present; this ranged from 1 to 231 belugas for each $1 \mathrm{~km}^{2}$ cell. One must keep in mind that each group location was collected as a single point estimate and that the actual group may encompass a slightly larger area. The areas where larger groups

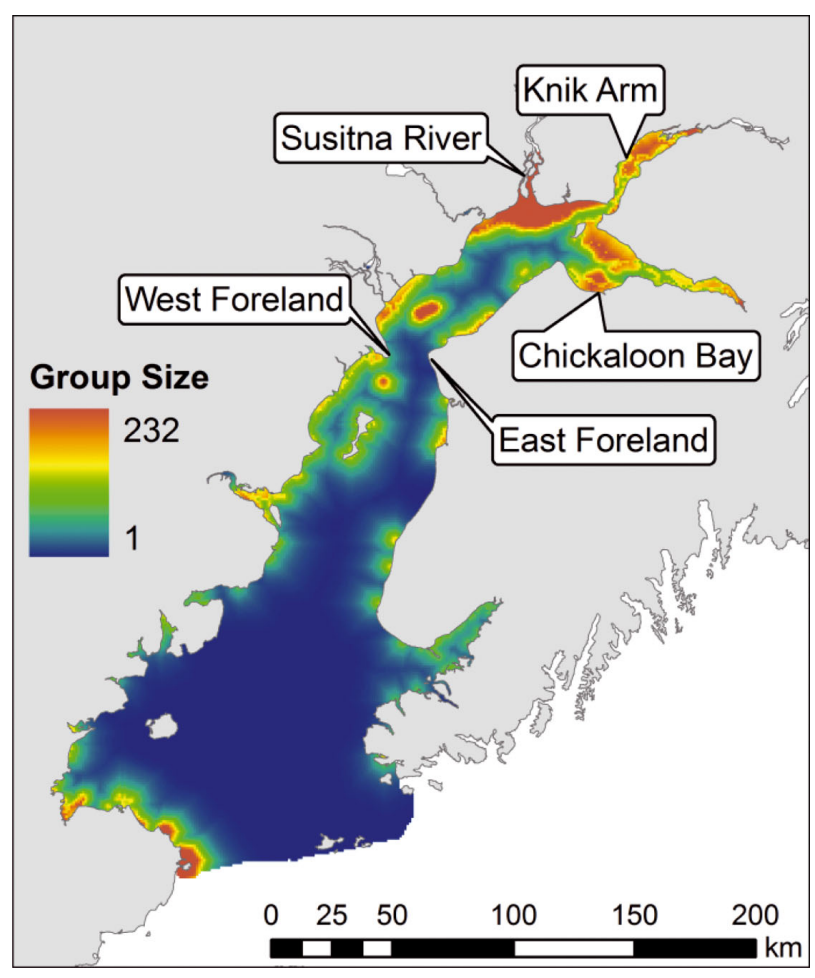

Fig. 5. Delphinapterus leucas. Predicted group size of belugas during the summer estimated by the generalized linear mixed effects model using Poisson regression are likely to occur are concentrated in the northern part of Cook Inlet (Fig. 5). The Susitna River Delta was the largest area in the northern inlet where belugas were likely to be found in high numbers.

\section{Combining the 2 model parts}

We combined the results from the 2 parts of the model to provide a meaningful synthesis of the habitat most important to beluga whales. To do this, we took the product of the 2 spatial grids from each part of the hurdle model - the probability of beluga presence (Fig. 3) and the expected beluga group size given their presence (Fig. 5) within the range of predicted habitat (Fig. 4). The product of the 2 grids produced a final grid that shows the expected number of belugas but does not distinguish between the frequent occurrence of small groups and the occasional occurrence of large groups. The number of belugas ranged from 0 to 1.12 animals per $1 \mathrm{~km}^{2}$ cell (Fig. 6). While there were a few coastal areas south of the Forelands where belugas are expected to be found, most animals are likely to be north of East and West Foreland, in Knik Arm, the Susitna River Delta, and Chickaloon Bay.

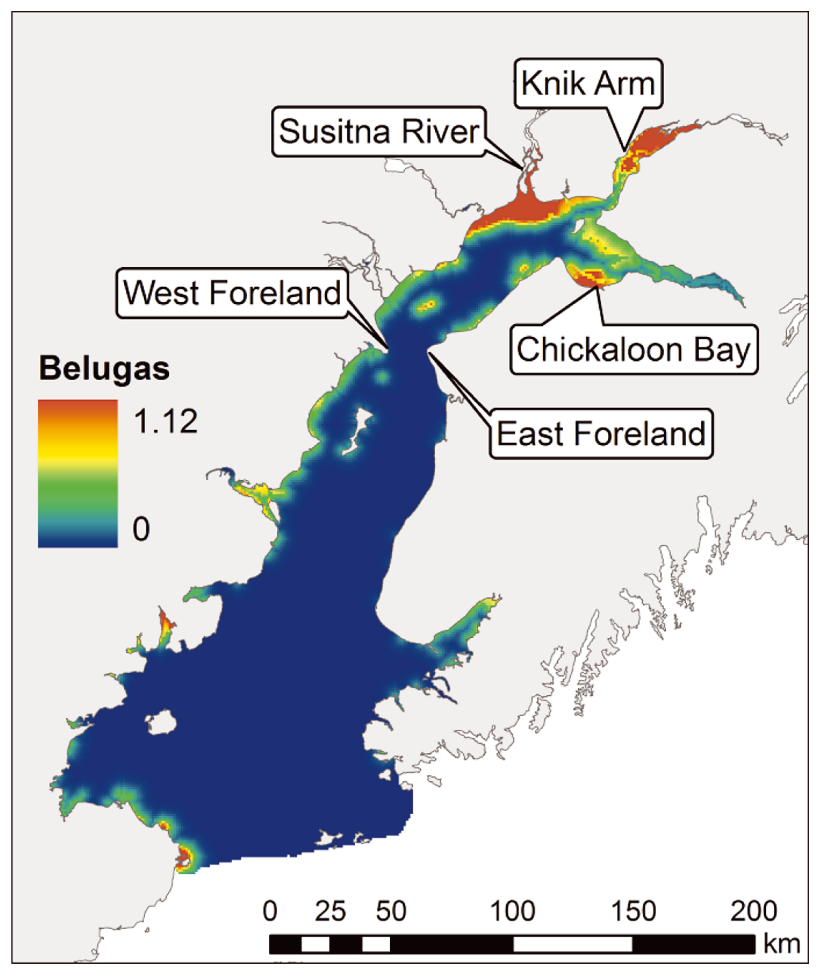

Fig. 6. Delphinapterus leucas. Expected number of belugas in each habitat unit $\left(1 \mathrm{~km}^{2}\right.$ cell) derived as the product (i.e. multiplication) of the probability of beluga presence and the expected number of belugas when they are present 


\section{DISCUSSION}

Lowry (1985) identified access to food, escape from predators, and water quality as the top factors influencing beluga distribution during ice-free months. The importance of these 3 factors is undoubtedly linked to life history processes such as feeding, calving, and molting, which, if interrupted, may prevent the recovery of the Cook Inlet beluga population. Although natural disturbances, such as those leading to lower fish runs, likely have the strongest impact on Cook Inlet belugas, habitat degradation due to increased anthropogenic activities such as vessel traffic, anthropogenic noise, water pollution, coastal development, and fishing may impede the recovery of this population in the long term (Moore et al. 2000).

Results from this analysis predicted $2857 \mathrm{~km}^{2}$ of summer habitat, which is consistent with the overall pattern and size of suitable Cook Inlet beluga habitat presented by Goetz et al. (2007). Conservation efforts should focus on protecting areas that take into account the combination of environmental variables included in our final model. While competing stakeholder interest for Cook Inlet resources may preclude the protection of all summer habitat areas identified by this analysis, efforts should be made to conserve as much contiguous habitat as possible to prevent the further decline of this already endangered population.

The hurdle model confirmed that, during the summer, 1 subset of environmental covariates is important in determining beluga presence while another subset is important in predicting beluga group size when they are present. There is a greater probability of belugas being present closer to rivers with Chinook salmon runs, rivers with medium flow accumulation, tidal flats, and areas with sandy coastlines. Probability of presence decreases closer to rivers with chum salmon, rivers with high flow accumulation, communities, oil development, and coastal areas with rocky substrate. When predicting the size of the beluga group present, however, larger groups tended to be found closer to rivers with high flow accumulation and closer to tidal flats, whereas group size decreases closer to coastal areas with sandy substrate. While the 2 predictions appear to be contradictory, the 2 models have enabled us to distinguish areas where belugas frequently occur and where they occasionally occur in large numbers, which would not have been possible using a single model.

The results from this model complement previous work in which belugas were found to prefer areas closer to mudflats (because most tidal flats are mudflats, the mudflat covariate used in previous studies is similar to the DISTTFLAT covariate used in this model (i.e. in the present study); Goetz et al. 2007). Tidal flats influenced both the presence and group size of beluga whales, as they were more likely to be present and in larger numbers near to tidal flats. Beluga proximity to mudflats may be related to their seasonal molt (St. Aubin et al. 1990, Watts et al. 1991). While the predominantly muddy bottom of upper Cook Inlet may not be abrasive enough to remove dead skin, the combination of rubbing and warm, fresh water could facilitate the sloughing of the epidermal layer (Finley 1982). The muddy substrate also facilitates the formation of narrow, shallow channels that may increase the feeding efficiency of belugas near river mouths (Frost et al. 1983).

The association of belugas with tidal flats may also be indirectly linked to prey availability. According to Bjornn \& Reiser (1991), stream flow must be strong enough to provide adequate discharge to cover the gravel substrates found in many streams. The results of the hurdle model support these findings, indicating that the probability of belugas being present increased closer to shores dominated by sand (DISTSAND) and tidal flats (DISTTFLAT) and decreased closer to shores where rock and gravel are the dominant substrates (DISTROCK). However, the group size of beluga whales was largely determined by rivers with high flow accumulation. The fact that group size decreased closer to coastal areas with sandy substrate is likely due to the low occurrences of sand on the west side of the upper inlet where belugas often occur in large numbers.

While Goetz et al. (2007) found distance to high flow accumulation rivers to be significant in predicting beluga presence, the results from the hurdle model presented here indicate that beluga presence decreased closer to high flow accumulation rivers but that group size increased closer to such rivers. These results suggest that when belugas are present in these areas they are in large compact groups. Upon visual inspection of the locations where high flow accumulation rivers enter the inlet, the results of the hurdle model appear logical; medium flow accumulation rivers are twice as common as high flow accumulation rivers in upper Cook Inlet, areas north of the Forelands, where most belugas are found. Thus, belugas are more likely to be closer to medium flow accumulation rivers than to high flow accumulation rivers, although larger groups of belugas tend to favor higher flow accumulation rivers.

Belugas' selection of medium and high flow accumulation rivers indicates a preference for larger river basins. Association of belugas with estuarine envi- 
ronments and their movements into large rivers may result from frequent concentrations of migratory fish such as smelt or salmon which ascend rivers to spawn (Lensink 1961). Physical factors such as basin size, flow rate, tide, current, salinity, and water temperature which directly influence fish may indirectly impact prey of beluga whales (Moore et al. 2000). Water flow is an important characteristic of fish habitat (Dorava \& Milner 2000). Salmon require stream flows of adequate depth and velocities to successfully travel upstream. Also, the number of spawning fish is limited by the area of suitable habitat (Bjornn \& Reiser 1991). As flow increases, more habitat becomes available for spawning anadromous fish. However, flow velocities that are too high will decrease the actual spawning capacity of the stream (Hooper 1973). Consequently, flow accumulation may not be a perfect predictor of the size of anadromous fish runs and available prey for beluga whales. In addition, glacier-fed rivers such as those in Cook Inlet have daily and seasonal variation in stream flow (Fountain \& Tangborn 1985) which were not accounted for in the hurdle model. Future models would benefit from the inclusion of empirical flow measurements to account for environmental stochasticity and direct measurements of anadromous fish spawning habitat and run size.

Cook Inlet belugas are known to feed on a variety of seasonally available fish species (Hobbs et al. 2008). Belugas switch from consuming eulachon Thaleichthys pacificus in the spring to lipid-rich species (Abookire \& Piatt 2005, Litzow et al. 2006) such as Pacific salmon (Oncorhynchus spp.) in the late spring and summer. Pacific salmon had the greatest percent frequency of occurrence of the prey species found in the stomachs of Cook Inlet belugas (Hobbs et al. 2008). In fact, Pacific salmon were the only fish species present in the 3 stomachs collected during the time of our surveys (Hobbs et al. 2008), coincident with seasonal fish runs. Our model results indicated that beluga presence increased closer to rivers with Chinook salmon runs. Because individual species identification is often not possible, assessing the importance of each of the 5 salmon species to belugas is difficult. According to traditional knowledge, whole Chinook salmon were found in the stomachs of adult beluga whales on several occasions (Huntington 2000). Although our model also suggests that belugas prefer to be near rivers with Chinook salmon, they likely feed on all species of salmon when available.

The abundance of 5 species of salmon, herring, scallops, halibut, and several other bottom fish make Cook Inlet one of the most productive fisheries in
Alaska (CIRCAC 1999). While many of these fish species are economically valuable to humans, they are energetically critical to the sustainability and potential recovery of the Cook Inlet population of beluga whales. Due to reduced prey abundance over the winter, belugas exhibit thin skin and reduced blubber thickness $(2$ to $3 \mathrm{~cm}$ ) in early spring (Huntington 2000). However, after feeding extensively on anadromous fish runs throughout the spring and summer, belugas can have blubber up to $30 \mathrm{~cm}$ thick by fall. In addition to recouping body mass during this time, female belugas may be pregnant or nursing a newborn calf (Kleinenberg et al. 1964, Sergeant \& Brodie 1969, Sergeant 1973, Braham 1984, Huntington 2000). Because calves do not feed on fish until about 12 mo of age (Burns \& Seaman 1986), adult females must consume more prey to meet the increased energetic demands of lactation.

Eulachon and salmon are the primary energetic prey items available during the summer (Payne et al. 1999, Abookire \& Piatt 2005). Feeding on fatty prey allows belugas to build enough fat reserves to meet metabolic demands and persist through the winter when food is scarce (NMFS 2008). Predicted summer habitat derived from this analysis may reflect areas where high prey abundance was available to meet the increased energetic demands of the season.

The areas of known eulachon and salmon runs and, thus, primary beluga feeding 'hotspots,' are the Susitna River Delta, Chickaloon Bay, Knik Arm, and along the west side of the upper inlet (NMFS 2008). In the first part of the model, the overall probability of beluga occurrence in Cook Inlet ranged from 0 to $0.01 \mathrm{~km}^{-2}$. While this maximum probability seems low, when large areas such as the Susitna River Delta $\left(239 \mathrm{~km}^{2}\right)$ and the Knik Arm $\left(325 \mathrm{~km}^{2}\right)$ are considered, there are 0.64 and 0.75 probabilities, respectively, that 1 or more groups will be found on any given survey day. The results from both parts of the hurdle model also confirm these locations as areas with a high probability of beluga presence as well as areas where beluga groups are likely to be larger when they are present (Figs. 3, 5, \& 6). The importance of the Susitna River Delta to Cook Inlet belugas is likely due to this area's ability to not only support summer salmon runs but also the 2 major spawning migrations of eulachon, the first in May and the second in July. The second run, overlapping our survey period, is estimated at several million fish (Calkins 1989). Consequently, we can interpret our results as indicating that the summer distribution of Cook Inlet belugas is most likely determined by feeding opportunities. 
Anthropogenic disturbance, including distances to both human communities (DISTCOMM) and oil development (DISTOIL), were also significant predictors of beluga whale presence. The probability of beluga presence decreased closer to both coastal cities and oil rigs. This finding may reflect the fact that human communities and oil development areas are associated with higher boat traffic (Allen et al. 1984), air traffic (Moore et al. 2000), and pollution (Reijnders 1984). However, these results should be interpreted with caution, as most of the human communities are located on the east coast of the lower inlet, and oil platforms are located well south of the Susitna Delta where belugas are commonly seen in the summer. Therefore, the results of our analysis might be driven more by beluga preference for rivers with available prey rather than an aversion to development. Further research, which looks specifically at beluga whale presence/group size in relation to human communities and oil platforms, would be required to tease out the intricacies of these relationships.

\section{CONCLUSIONS AND IMPLICATIONS FOR CONSERVATION}

This analysis identified key covariates in predicting the summer habitat of Cook Inlet beluga whales. Our hurdle model demonstrates that the availability of prey is a critical determinant of beluga whale distribution and group size. Measures of prey abundance and distribution would likely be better predictors of beluga presence and group size than static environmental covariates. However, the most biologically relevant data are often the most sparse, as is the case for fish escapement data in Cook Inlet. Salmon escapement numbers have fluctuated widely throughout the last $40 \mathrm{yr}$, yet samples from stranded belugas show that blubber thickness has not fluctuated over the years (NMFS 2008). Because many of the beluga prey species have relatively little economic importance, they are not monitored in a manner suitable for quantitative analysis. In addition, Cook Inlet is divided into many management areas (Hammarstrom \& Ford 2009, Shields 2009), often resulting in fish monitoring methods that are not comparable. Inconsistent management regulations and data biases towards commercially valuable fish may result in unintentional negative impacts. Without rigorous monitoring of all salmon and eulachon runs in Cook Inlet, declines in prey species abundance may go unno- ticed and have dire consequences for this already fragile beluga population.

Even though only $2 \%$ of the 331 beluga groups were sighted south of East and West Foreland (Figs. 1 \& 2), the first part of the hurdle model predicted suitable beluga habitat along much of the southern inlet coastline (Fig. 4). In the past, belugas were present in the lower inlet, but after several years of unregulated hunting in the 1990s, beluga sightings in the lower inlet have become increasingly rare (Rugh et al. 2010). Productive fish runs, decreased predation risk, and historical precedence are all possible reasons for the persistence of beluga whales in northern Cook Inlet despite past hunting pressure and increased industrial development (Rugh et al. 2010). The majority of predicted habitat along the coast is consistent with beluga behavior in which they generally utilize shallow coastal waters, barely deep enough to cover their bodies (Ridgway \& Harrison 1981). This affinity for coastal areas is likely due to feeding strategies and may also correlate with calving, molting, and protection from predators or inclement weather. The reduced population of belugas is likely using a limited range of currently available habitat (Rugh et al. 2010), and a reoccupation of suitable habitat throughout Cook Inlet can be expected if this population recovers to historic levels.

Acknowledgements. NMFS aerial surveys were conducted under the Marine Mammal Protection Act Scientific Research Permit Nos. 791, 782-1360, and 782-1719. Helpful reviews of this document were provided by K. Shelden, K. Call, P. Clapham, and D. DeMaster. We thank all the biologists and flight crew who flew many long days. Reference to trade names does not imply endorsement by NMFS, NOAA. The findings and conclusions in this paper are those of the author(s) and do not necessarily represent the views of NMFS.

\section{LITERATURE CITED}

Abookire AA, Piatt JF (2005) Oceanographic conditions structure forage fishes into lipid-rich and lipid-poor communities in lower Cook Inlet, Alaska, USA. Mar Ecol Prog Ser 287:229-240

Allen SG, Ainley DG, Page GW, Ribic CA (1984) The effect of disturbance on harbor seal haul out patterns at Bolinas Lagoon, California. Fish Bull 82:493-500

Atkinson B, Mahoney D (2004) S-Plus ROC functions. Mayo Foundation for Medical Education and Research, Rochester, MN

Baumgartner MF, Cole TVN, Campbell RG, Teegarden GJ, Durbin EG (2003) Associations between North Atlantic right whales and their prey, Calanus finmarchicus, over diel and tidal time scales. Mar Ecol Prog Ser 264:155-166

Bjornn TC, Reiser DW (1991) Habitat requirements of salmonids in streams. In: Meehan WR (ed) Influences of forest and rangeland management on salmonid fishes and 
their habitats. American Fisheries Society Spec Publ 19. American Fisheries Society, Bethesda, MD, p 83-138

Bolker BM, Brooks ME, Clark CJ, Geange SW, Poulsen JR, Stevens MHH, White JSS (2009) Generalized linear mixed models: a practical guide for ecology and evolution. Trends Ecol Evol 24:127-135

Bouma AH, Hampton MA, Orlando RC (1977) Sand waves and other bedforms in lower Cook Inlet, Alaska. Mar Georesour Geotechnol 2:291-308

Braham HW (1984) Review of reproduction in the white whale, Delphinapterus leucas, narwhal, Monodon monoceros, and Irrawaddy dolphin, Orcaella brevirostris, with comments on stock assessment. Rep Int Whal Comm Spec Issue 6:81-89

Burns JJ, Seaman GA (1986) Investigations of belukha whales in coastal waters of western and northern Alaska. II. Biology and ecology. US Dept Commerce, NOAA, OCSEAP Final Rep 56 (1988):221-357

Calkins DG (1989) Status of belukha whales in Cook Inlet. In: Jarvela LE, Thorsteinson LK (eds) Proceedings of the Gulf of Alaska, Cook Inlet, and North Aleutian Basin Information Update Meeting, Anchorage, AK, Feb. 7-8. US Dept Commerce, NOAA, OCSEAP, Anchorage, AK, p 109-112

CIRCAC (Cook Inlet Regional Citizen Advisory Council) (1999) Safety of navigation in Cook Inlet. CIRCAC, Homer, AK

> Dorava JM, Milner AM (2000) Role of lake regulation on glacier-fed rivers in enhancing salmon productivity: the Cook Inlet watershed, south-central Alaska, USA. Hydrol Process 14:3149-3159

Finley KJ (1982) The estuarine habitat of the beluga or white whale, Delphinapterus leucas. Cetus 4:4-5

Fountain AG, Tangborn WV (1985) The effect of glaciers on streamflow variations. Water Resour Res 21:579-586

Frost KJ, Lowry LF, Nelson RR (1983) Investigations of belukha whales in coastal waters of western and northern Alaska, 1982-1983: marking and tracking of whales in Bristol Bay. US Dept Commerce, NOAA, OCSEAP Final Rep 43(1986):461-585

- Goetz KT, Rugh DJ, Read AJ, Hobbs RC (2007) Habitat use in a marine ecosystem: beluga whales Delphinapterus leucas in Cook Inlet, Alaska. Mar Ecol Prog Ser 330: $247-256$

Gregr EJ, Trites AW (2001) Predictions of critical habitat for five whale species in the waters of coastal British Columbia. Can J Fish Aquat Sci 58:1265-1285

Hammarstrom LF, Ford EG (2009) 2008 Lower Cook Inlet annual finfish management. Report No. 09-28. Alaska Department of Fish and Game, Homer, AK

Harney JN, Morris MM, Harper JR (2008) ShoreZone coastal habitat mapping protocol for the Gulf of Alaska. Available at www.coastalandoceans.com/downloads.html

Hobbs RC, Rugh DJ, DeMaster DP (2000) Abundance of belugas, Delphinapterus leucas, in Cook Inlet, Alaska, 1994-2000. Mar Fish Rev 62:37-45

Hobbs RC, Laidre KL, Vos DJ, Mahoney BA, Eagleton M (2005) Movements and area use of belugas, Delphinapterus leucas, in a subarctic Alaskan estuary. Arctic 58:331-340

Hobbs RC, Shelden KEW, Rugh DJ, Norman SA (2008) 2008 status review and extinction risk assessment of Cook Inlet belugas (Delphinapterus leucas). AFSC Processed Rep 2008-02, National Marine Fisheries Service, Seattle, WA
Hooper DL (1973) Evaluation of the effects of flows on trout stream ecology. Department of Engineering Research, Pacific Gas \& Electric Co, Emeryville, CA

Huntington HP (2000) Traditional knowledge of the ecology of belugas, in Cook Inlet, Alaska. Mar Fish Rev 62: $134-140$

Johnson J, Weiss A (2007) Catalog of waters important for spawning, rearing, or migration of anadromous fishes Southcentral region, effective June 1, 2007. Spec Publ 07-05, Alaska Department of Fish and Game, Anchorage, $\mathrm{AK}$

Kleinenberg SE, Yablokov AV, Bel'kovich BM, Tarasevich MN (1964) Beluga (Delphinapterus leucas). Investigations of the species. Izdatel'stvo Nauka, Moscow (transl. from Russian by Israel Program for Scientific Translation, Jerusalem, 1969)

Laidre KL, Shelden KEW, Rugh DJ, Mahoney BA (2000) Beluga (Delphinapterus leucas) distribution and survey effort in the Gulf of Alaska. Mar Fish Rev 62:27-36

Lensink CJ (1961) Status report: beluga studies. Annual report for 1958. Unpublished report for the Alaska Department of Fish and Game, Juneau, AK (Available on request from ADF\&G Div. Wildlife Conservation, Fairbanks, AK)

Litzow MAK, Bailey KM, Prahl FG, Heintz R (2006) Climate regime shifts and reorganization of fish communities: the essential fatty acid limitation hypothesis. Mar Ecol Prog Ser 315:1-11

Lowry LF (1985) The beluka whale (Delphinapterus leucas). In: Burns JJ, Frost KJ, Lowry LF (eds) Marine mammals species accounts. Tech Bull 7. Alaska Department of Fish and Game, Juneau, AK, p 3-13

Moore SE, Shelden KEW, Litzky LK, Mahoney BA, Rugh DJ (2000) Beluga habitat associations in Cook Inlet, Alaska. Mar Fish Rev 62:60-80

Muench RD, Mofjeld HO, Charnell RL (1978) Oceanographic conditions in lower Cook Inlet - spring and summer 1973. J Geophys Res 83:5090-5098

NMFS (National Marine Fisheries Service) (2008) Conservation plan for the Cook Inlet beluga whale (Delphinapterus leucas). NMFS, Juneau, AK

O'Corry-Crowe GM, Suydam RS, Rosenberg A, Frost KJ, Dizon AE (1997) Phylogeography, population structure and dispersal patterns of the beluga whale Delphinapterus leucas in the western Nearctic revealed by mitochondrial DNA. Mol Ecol 6:955-970

- Payne SA, Johnson BA, Otto RS (1999) Proximate composition of some north-eastern Pacific forage fish species. Fish Oceanogr 8:159-177

> Pearce J, Ferrier S (2000) An evaluation of alternative algorithms for fitting species distribution models using logistic regression. Ecol Model 128:127-147

$>$ Redfern JV, Ferguson MC, Becker EA, Hyrenbach KD and others (2006) Techniques for cetacean-habitat modeling. Mar Ecol Prog Ser 310:271-295

> Reijnders PJH (1984) Man-induced environmental factors in relation to fertility changes in pinnipeds. Environ Conserv 11:61-65

Ridgway S, Harrison SR (eds) (1981) Handbook of marine mammals, Vol 4: river dolphins and the larger toothed whales. Academic Press, London

Rugh DJ, Mahoney BA, Smith BK (2004) Aerial surveys of beluga whales in Cook Inlet, Alaska, between June 2001 and June 2002. NOAA Tech Memo NMFS-AFSC-145. National Marine Fisheries Service, Seattle, WA 
Rugh DJ, Shelden KEW, Sims CL, Mahoney BA, Smith BK, Litzky LK, Hobbs RC (2005) Aerial surveys of belugas in Cook Inlet, Alaska, June 2001, 2002, 2003, and 2004. NOAA Tech Memo NMFS-AFSC-149. National Marine Fisheries Service, Seattle, WA

Rugh DJ, Shelden KEW, Hobbs RC (2010) Range contraction in a beluga whale population. Endang Species Res 12: $69-75$

Schall R (1991) Estimation in generalized linear models with random effects. Biometrika 78:719-727

Schick RS, Halpin PN, Read AJ, Slay CK and others (2009) Striking the right balance in right whale conservation. Can J Fish Aquat Sci 66:1399-1403

Sergeant DE (1973) Biology of white whale (Delphinapterus leucas) in western Hudson Bay. J Fish Res Board Can 30: 1065-1090

Sergeant DE, Brodie PF (1969) Body size in white whales, Delphinapterus leucas. J Fish Res Board Can 26:25612580

Sharma GD, Burrell DC (1970) Sedimentary environment and sediments of Cook Inlet, Alaska. Am Assoc Petrol Geol Bull 54:647-654

Shields P(2009) Upper Cook Inlet commercial fisheries annual management report, 2008. Fisheries Manage-

Editorial responsibility: Kristin Laidre,

Seattle, Washington, USA ment Report 09-32. Alaska Department of Fish and Game, Anchorage, AK

St. Aubin DJ, Smith TG, Geraci JR (1990) Seasonal epidermal molt in beluga whales, Delphinapterus leucas. Can J Zool 68:359-367

Thuiller W, Araújo MB, Lavorel S, Kenkel N (2003) Generalized models vs. classification tree analysis: predicting spatial distributions of plant species at different scales. J Veg Sci 14:669-680

Venables WN, Ripley BD (2002) Random and mixed effects. In: Chambers J, Eddy W, Hardle W, Sheather S, Tierney L (eds) Modern applied statistics with S: statistics and computing. Springer-Verlag, New York, NY, p 271-299

Vos DJ (2003) Cook Inlet beluga age and growth. MSc thesis, Alaska Pacific University, Anchorage, AK

Watts PD, Draper BA, Henrico J (1991) Preferential use of warm water habitat by adult beluga whales. J Therm Biol 16:57-60

Zuur AF, Ieno EN, Walker NJ, Saveliev AA, Smith GM (2009) Zero-truncated and zero-inflated models for count data. In: Gail M, Krickeberg K, Samet JM, Tsiatis A, Wong W (eds) Mixed effects models and extensions in ecology with R. Springer Science+Business Media, New York, NY, p 261-293

Submitted: January 10, 2011; Accepted: October 14, 2011

Proofs received from author(s): February 5, 2012 